\title{
PENATAAN PERMUKIMAN KUMUH DI DESA NANAS SIAM KECAMATAN MEDANG DERAS KABUPATEN BATUBARA PROPINSI SUMATERA UTARA
}

\author{
Ova Novi Irama, SE, M.Ak \\ Fakultas Ekonomi Universitas Muslim Nusantara Al-Washliyah Medan \\ Suhaila Husna Samosir, SE, MM \\ Fakultas Ekonomi Universitas Muslim Nusantara Al-Washliyah Medan \\ *Corresponding author: E-mail: novi12345za@gmail.com, Suhailahusna1990@yahoo.co.id
}

\begin{abstract}
Indonesia's urban slum neighborhood is a very complex problem, including problems related to poverty, low levels of community education, gaps and indiscriminately to the environment as well as the capacity of city / district government institutions in regulating, organizing spatial planning and resources owned. One of them in the Village Nanas Siam Kecamatamn Medang Deras Batubara District. Problems that occur in the field was quite complex. Many of the things that affect the emergence and the process of the region into a slum with a variety of characteristics of the problem. From the results of research can be seen that the condition of slum neighborhoods in the village of Nanas Siam Kecamatamn Medang Deras Batubaram regency is very bad. This can be seen from the density of buildings in the area that are not in accordance with the spatial planning that may cause flood and fire hazard. In addition, the low level of environmental hygiene and hygiene facilities and infrastructure in the slums.
\end{abstract}

Keywords: Structuring, Slum Areas 


\section{PENDAHULUAN}

\section{Latar Belakang Masalah}

Perkembangan permukiman di daerah perkotaan tidak terlepas dari pesatnya laju pertumbuhan penduduk perkotaan baik karena faktor pertumbuhan penduduk kota itu sendiri maupun karena faktor urbanisasi. Dampak negatif urbanisasi yang telah berlangsung selama ini lebih disebabkan oleh tidak seimbangnya peluang untuk mencari nafkah di daerah perdesaan dan perkotaan. Beberapa pengamat meyakini bahwa salah satu penyebab mengalirnya penduduk pedesaan ke kota-kota akibat kekeliruan adopsi paradigma pembangunan yang menekankan pada pembangunan industrialisasi besar-besaran yang ditempatkan di kota-kota besar yang kemudian dikenal dengan istilah AIDS (Accelerated Industrialization Development Strategy), sehigga memunculkan adanya daya tarik yang sangat kuat untuk mengadu nasibnya di kota yang dianggap mampu memberikan masa depan yang lebih baik dengan penghasilan yang lebih tinggi, sementara pendidikan dan ketrampilan yang mereka miliki kurang memadai untuk masuk disektor formal (Yunus, 2005). Seiring dengan pertumbuhan penduduk di daerah perkotaan, maka kebutuhan penyediaan akan prasarana dan sarana permukiman akan meningkat pula, baik melalui peningkatan maupun pembangunan baru. Selanjutnya pemenuhan akan kebutuhan prasarana dan sarana permukiman baik dari segi perumahan maupun lingkungan permukiman yang terjangkau dan layak huni belum sepenuhnya dapat disediakan baik oleh masyarakat sendiri maupun pemerintah, sehingga kapasitas daya dukung prasarana dan sarana lingkungan permukiman yang ada mulai menurun yang pada gilirannya memeberikan kontribusi terjadinya lingkungan permukiman kumuh.
Dari fenomena tersebut dapat dipetik pelajaran bahwa penanganan lingkungan permukiman kumuh tidak dapat diselesaikan secara sepihak, tetapi harus secara sinergis melibatkan potensi dan eksistensi dari seluruh pihak yang berkepentingan (stakeholders), baik Pemerintah Pusat, Provinsi, Kabupaten/Kota maupun masyarakat sendiri selaku penerima manfaat, Pelaku dunia usaha, LSM/NGO, cerdik pandai dan pemerhati yang peduli. Apabila hal ini tidak disiapkan penanggulanganya sejak dini, maka masalah pemukiman kumuh akan menjadi masalah ketidakmampuan kota dalam menjalankan perannya sebagai pusat pembangunan sosial, ekonomi dan politik (Sri, 1988).

\section{Tujuan Penelitian}

Adapun tujuan dari penelitian ini adalah sebagai berikut:

1. Untuk mengetahui Bagaimana kondisi lingkungan permukiman kumuh di Desa Nanas Siam Kecamatan Medang, Deras Kabupaten Batubara.

2. Untuk mengetahui Bagaimana kondisi sosial ekonomi \& budaya masyarakat yang terdapat di lingkungan permukiman kumuh di Desa Nanas Siam Kecamatan Medang Deras, Kabupaten Batubara

\section{Manfaat Penelitian}

Adapun manfaat dari penelitian ini adalah mempunyai konstribusi dalam kegiatan penataan permukiman kumuh khususnya di Desa Nanas Siam Kecamatan Medang Deras Kabupaten Batu Bara sejalan dengan telah di munculkan nya anggaran dana desa pada setiap desa yang ada di Sumatera Uatara.

\section{KAJIAN LITERATUR \\ PENGEMBANGAN HIPOTESIS}

DAN 


\section{Permukiman Penduduk \\ Persyaratan Permukiman}

Suatu bentuk permukiman yang ideal di kota merupakan pertanyaan yang menghendaki jawaban yang bersifat komprehensif, sebab perumahan dan permukiman menyangkut kehidupan manusia termasuk kebutuhan manusia yang terdiri dari berbagai aspek. Sebingga dapat dirumuskan secara sederhana tentang ketentuan yang baik untuk suatu permukiman yaitu harus memenuhi sebagai berikut:

1) Lokasinya sedemikian rupa sehingga tidak terganggu oleh kegiatan lain

seperti pabrik, yang umumnya dapat memberikan dampak pada pencemaran udara atau pencemaran lingkungan lainnya

2) Mempunyai akses terhadap pusat- pusat pelayanan seperti pelayanan

pendidikan, kesehatan, perdagangan, dan lain-lain

3) Mempunyai fasilitas drainase, yang dapat mengalirkan air hujan dengan cepat dan tidak sampai menimbulkan genangan air walaupun hujan yang lebat sekalipun

4) Mempunyai fasilitas penyediaan air bersih, berupa jaringan distribusi yang siap untuk disalurkan ke masing-masing rumah.

5) Dilengkapi dengan fasilitas air kotor/tinja yang dapat dibuat dengan sistem individual yakni tangki septik dan lapangan rembesan, ataupun tanki septik komunal.

\section{Karakteristik Permukiman Kumuh}

Permukiman adalah bagian dari lingkungan hidup di luar kawasan lindung, dapat merupakan kawasan perkotaan dan perdesaan, berfungsi sebagai lingkungan tempat tinggal/hunian dan tempat kegiatan yang mendukung perikehidupan dan penghidupan.

Menurut UU No.1 Tahun 2011, Kawasan Pertanian Pangan Berkelanjutan adalah wilayah budi daya pertanian terutama pada wilayah perdesaan yang memiliki hamparan Lahan Pertanian Pangan Berkelanjutan dan/atau hamparan Lahan Cadangan Pertanian Pangan Berkelanjutan serta unsur penunjangnya dengan fungsi utama untuk mendukung kemandirian, ketahanan, dan kedaulatan pangan nasional.

Menurut Silas, dkk (1991)

Permukiman Kumuh dapat diartikan menjadi dua bagian, yang pertama ialah kawasan yang proses terbentukannya karena keterbatasan kota dalam menampung perkembangan kota sehingga timbul kompetisi dalam menggunakan lahan perkotaan. Sedangkan kawasan permukiman berkepadatan tinggi rnerupakan embrio permukiman kumuh. Dan yang kedua ialah kawasan yang lokasi penyebarannya secara geografis terdesak perkembangan kota yang semula baik, lambat laun menjadi kumuh. Perkembangan kota yang kumuh disebabkan oleh mobilitas sosial perekonomian yang stagnan.

Adapun Karakteristik Permukiman Kumuh antara lain :

1) Keadaan rumah pada permukiman kumuh terpaksa dibawah standar, ratarata $6 \mathrm{~m} 2$

2) Permukiman ini secara fisik memberi /orang. Sedangkan fasilitas kekotaan secara langsung tidak terlayani karena tidak tersedia. Namun karena lokasinya dekat dengan permukiman yang ada, maka fasilitas Iingkungantersebut tak sulit mendapatkannya.

3) Manfaat pokok, yaitu dekat tempat mencari nafkah (opportunity value) dan harga rumah juga murah (asas keterjangkauan) baik membeli atau menyewa. Manfaat permukiman disamping pertimbangan lapangan kerja dan harga murah adalah kesempatan mendapatkannya atau 
aksesibilitas tinggi. Hampir setiap orang tanpa syarat yang bertele-tele pada setiap saat dan tingkat kemampuan membayar apapun, selalu dapat diterima dan berdiam di sana, termasuk masyarakat "residu" seperti residivis dan lain-lain (Silas dkk, 1991).

\section{Faktor yang Menyebabkan Terbentuknya Permukiman Kumuh}

Sungai menurut Peraturan

Pemerintah No. 35 Tahun 1999 sebagai suatu tempat atau wadah serta jaringan pengaliran air mulai dari mata air sampai muara dengan dibatasi kanan dan kirinya serta disepanjang pengalirannya oleh garis sepadan. Sungai telah memegang peranan yang sangat penting dalam sejarah perkembangan peradaban dan kebudayaan manusia. Pada awal pertumbuhannyatelah ditandai dengan terbentuknya suatu konsentrasi penduduk dengan membentuk kelompok pemukiman tertentu di lembah sungai yang subur. Peranan sungai di dalam kehidupan sehari-hari, dengan adanya air, manusia memanfaatkan untuk minum, mandi dan mencuci.

Kemudian

peran

sungai

berkembang menjadi sarana transportasi, yang mendorong pertumbuhan pennukiman seiring dengan laju pertumbuhan penduduk dan aktifitas sosial ekonominya makin lama peranannya makin berkembang dan tidak terpisahkan lagi dari keseluruhan sistem pelayan. Pesatnya pertambahan jumlah penduduk di perkotaan akibat dari jumlah kelahiran dan perpindahan penduduk dari pedesaan ke kota, akan berpengaruh langsung terhadap kebutuhan sarana prasarana kota dalam hal ini menyangkut kebutuhan akan perumahan dan permukiman di perkotaan itu sendiri.

\section{Permasalahan yang Timbul Akibat Permukiman Kumuh}

Perumahan kumuh dapat mengakibatkan berbagai dampak. Dari segi pemerintahan, pemerintah dianggap dan dipandang tidak cakap dan tidak peduli dalam menangani pelayanan terhadap masyarakat, Sementara pada dampak sosial, dimana sebagian masyarakat kumuh adalah masyarakat berpenghasilan rendah dengan kemampuan ekonomi menengah ke bawah dianggap sebagai sumber ketidakteraturan dan ketidakpatuhan terhadap norma-norma sosial.

Terbentuknya pemukiman kumuh, yang sering disebut sebagai slum area. Daerah ini sering dipandang potensial menimbulkan banyak masalah perkotaan, karena dapat merupakan sumber timbulnya berbagai perilaku menyimpang, seperti kejahatan, dan sumber penyakit sosial lainnya. Penduduk di permukiman kumuh tersebut memiliki persamaan, terutama dari segi latar belakang sosial ekonomi-pendidikan yang rendah, keahlian terbatas dan kemampuan adaptasi lingkungan (kota) yang kurang memadai. Kondisi kualitas kehidupan yang serba mariginal ini temyata mengakibatkan semakin banyaknya penyimpangan perilaku penduduk penghuninya. Hal ini dapat diketahui dari tatacara kehidupan sehari-hari, seperti mengemis, berjudi, mencopet dan melakukan berbagai jenis penipuan.

Mereka pada umumnya tidak cukup memiliki kemampuan untuk mendapatkan pekerjaan yang layak, disebabkan kurangnya keterampilan, tanpa modal usaha, tempat tinggal tak menentu, rendahnya penguasaan ilmu pengetahuan dan teknologi, rendahnya daya adaptasi sosial ekonomi dan pola kehidupan kota. Kondisi yang serba terlanjur, kekurangan dan semakin memprihatmkan itu mendorong para pendatang tersebut untuk hidup seadanya, termasuk tempat tinggal yang tidak memenuni syarat kesehatan.

\section{Pengaruh Permukiman Terhadap Lingkungan}

Kumuh 
Lingkungan permukiman kumuh memberi dampak yang bersifat multi dimensi diantaranya dalam dimensi penyelenggaraan pemerintahan, tatanan sosial budaya, lingkungan fisik serta dimensi politis. Di bidang penyelenggaraan pemerintahan, keberadaan lingkungan permukiman kumuh memberikan dampak citra ketidakberdayaan, ketidakmampuan dan bahkan ketidakpedulian pemerintah terhadap pengaturan pelayanan kebutuhan-kebutuhan hidup dan penghidupan warga kota maupun pendatang dan pelayanan untuk mendukung kegiatan sosial budaya, ekonomi, teknologi, ilmu pengetahuan, dan sebagainya.

Di bidang lingkungan/hunian komunitas penghuni lingkungan permukiman kumuh sebagian besar pekerjaan mereka adalah tergolong sebagai pekerjaan sektor informal yang tidak memerlukan keahlian tertentu, misalnya sebagai buruh kasar/kuli

bangunan, sehingga pada umumnya tingkat penghasilan mereka sangat terbatas dan tidak mampu menyisihkan penghasilannya untuk memenuhi kebutuhan perumahan dan permukiman sehingga mendorong terjadinya degradasi kualitas lingkungan yang pada gilirannya memunculkan terjadinya permukiman kumuh.

\section{Hipotesis Penelitian}

Dari kerangka konseptual diatas, maka hipotesis dari penelitian ini adalah "Penataan permukiman kumuh di Desa Nanas Siam Kecamatan Medang Deras Kabupaten batubara Provinsi Sumatera Utara".

\section{METODE PENELITIAN}

\section{Tempat dan Waktu Penelitian}

\section{Tempat Penelitian}

Dilaksanakan di Desa Nanas Siam Kecamatan Medang Deras, Kabupaten Batubara, Provinsi Sumatera Utara.

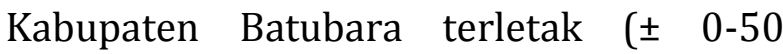
meter) diatas permukaan laut. Pemilihan lokasi penelitian dilakukan secara sengaja (purposive) disebabkan perlunya penataan permukiman kumuh di Desa Nanas Siam, Kecamatan Medang Deras, Kabupaten Batubara.

\section{Waktu penelitian}

Adapun waktu penelitian dalam penelitian ini adalah bulan Mei 2017 sampai Desember 2017.

\section{Rancangan Penelitian}

\section{Jenis Penelitian}

Penelitian deskriptif dilakukan untuk mengetahui kondisi lingkungan permukiman kumuh dan kondisi sosial ekonomi \& budaya masyarakat di Desa Nanas Siam, Kecamatan Medang Deras, Kabupaten Batubara.

\section{Teknik Pengumpulan}

Data Pengumpulan data kondisi lingkungan permukiman kumuh dilakukan dengan metode pengumpulan data primer. Pengumpulan data kondisi sosial ekonomi \& budaya masyarakat permukiman kumuh menggunakan metode pengumpulan data primer dan pengumpulan data aktif dengan wawancara langsung kepada responden.

\section{Teknik Penentuan Sampel}

$\begin{array}{ccr}\text { Sampel } & \text { penelitian } & \text { untuk } \\ \text { mengetahui } & \text { kondisi } & \text { lingkungan }\end{array}$


permukiman kumuh yakni masyarakat yang tinggal di Desa Nanas Siam, Kabupaten Medang Deras, Kabupaten Batubara. Sampel penelitian untuk keadaan sosial ekonomi \& budaya masyarakat permukiman kumuh diambil dengan cara memilih 50 orang informan dari 70 orang kepala keluarga di Desa Nanas Siam.. Jumlah sampel sebanyak $71 \%$ dari jumlah masyarakat yang menghuni permukiman kumuh dan dipilih secara acak (random sampling).

\section{Analisis Data}

Analisis yang digunakan untuk mengetahui kondisi lingkungan dan pengaruh kondisi sosial ekonomi masyarakat permukiman kumuh yakni Uji Validitas Kuisioner. Tahapan kegiatan Uji Kuisioner meliputi: 1) Pengukuran respon subyek ke dalam 5 poin skala dengan interval yang sama. Tipe data yang digunakan adalah tipe Interval Skala Likert (Likert Scale).Selanjutnya data responden yang telah diklasifikasikan dalam skala likert, dihitunga frekuensi untuk tiap variable. 2) Interpretasi hasil. Pengukuran interpretasi hasil penelitian menggunakan uji validitas isi (content validity) dilakukan berdasarkan nilai interval Skala Likert untuk menunjukkan tingkat besaran itemitem dari instrument yang mewakili konsep yang diukur. Jika instrumen yang digunakan mencakup topik yang didefinisikan sebagai dimensi dan elemen yang relevan menggambarkan konsepnya, maka dapat dikatakan bahwa instrument tersebut memiliki validitas isi yang baik.

\section{HASIL DAN PEMBAHASAN}

Deskripsi Daerah Penelitian Kabupaten Batubara

\section{Letak Geografis dan Batas Kabupaten Batu}

Bara merupakan salah satu Kabupaten di Propinsi Sumatera Utara yang baru terbentuk pada Tahun 2007 dengan letak astronomis 2003'00"3026'00" LU dan 99.001-100.000 BT, yang merupakan pemekaran dari Kabupaten Asahan. Kabupaten Batu Bara berada di kawasan Pantai Timur Sumatera Utara yang mempunyai batas-batas administratif Kabupaten Batu Bara antara lain: a. Utara : Kabupaten Serdang Bedagai b. Selatan : Kabupaten Asahan c. Barat : Kabupaten Simalungun d. Timur : Selat Malaka (Batubara Dalam Angka, 2009).

\section{Keadaan Fisik}

Kabupaten Batu Bara merupakan salah satu Kabupaten di Provinsi Sumatera Utara yang baru terbentuk pada tahun 2007, yang merupakan pemekaran dari Kabupaten Asahan. Batu Bara berada di kawasan Pantai Timur Sumatera Utara yang berbatasan dengan Selat Malaka. Kabupaten Batu Bara memiliki luas wilayah 90.496 Ha yang terdiri dari 7 Kecamatan serta 93 desa dan 7 kelurahan yang terdiri dari 1 desa swadaya mula, 25 desa swakarya mula, 6 swakarya madya, 62 desa swasembada mula dan 6 desa swasembada madya yang seluruhnya telah definitif. Dari 100 kepala desa atau lurah, 9 diantaranya dikepalai oleh perempuan atau sekitar $9 \%$. Kabupaten Batubara dibagi menjadi 7 Kecamatan sebagai berikut:

\section{Kecamatan Sei Balai}

2. Kecamatan Tanjung Tiram

\section{Kecamatan Talawi}

4. Kecamatan Lima Puluh

5. Kecamatan Air Putih

6. Kecamatan Sei Suka

7. Kecamatan Medang Deras 
Berdasarkan luas daerah menurut kecamatan, Kecamatan Lima Puluh Kabupaten Batu Bara merupakan kecamatan terluas dengan luas wilayah mencapai $239.55 \mathrm{~km}^{2}$ atau $26.47 \%$ dari luas total Kabupaten Batu Bara. Sedangkan Kecamatan Medang Deras merupakan wilayah terkecil dengan luas $65.47 \mathrm{~km}^{2}$ atau $7.23 \%$ dari luas total Kabupaten Batu Bara (Batubara Dalam Angka, 2009).

\section{Topografi}

Kabupaten Batubara Kabupaten Batu Bara terletak 0-50 meter dpl dengan prosentase kemiringan yakni:
a. $0-7 \mathrm{~m}=28,56 \%$
b. $7-25 \mathrm{~m}=22,69 \%$
c. $25-100 \mathrm{~m}=23,60 \%$
d. $100-500 m=15,89 \%$
e. $500-1000 \mathrm{~m}=4,27 \%$

Deskripsi Daerah Penelitian Kecamatan Medang Deras

\section{Keadaan Fisik}

Kecamatan Medang Deras merupakan bagian Kabupaten Batubara. Deskripsi daerah penelitian Kecamatan Medang Deras adalah sebagai berikut:
a. Sebelah Utara : Selat Malaka
b. Sebelah Timur : Selat Malaka
c. Sebelah Selatan : Kecamatan Sei Suka
d. Sebelah Barat : Kabupaten Serdang Bedagai (Batubara Dalam Angka, 2009).

\section{Iklim}

Seperti umumnya daerah-daerah lainnya yang berada di kawasan Sumatera Utara, Kabupaten Batu Bara termasuk daerah yang beriklim tropis dan memiliki dua musim yaitu musim kemarau dan musim hujan.

Menurut catatan Pos Pengukuran Perkebunan Sei Bejangkar, pada Tahun 2008 terdapat 95 hari hujan dengan volume curah hujan sebanyak $1.736 \mathrm{~mm}$. Curah hujan terbesar terjadi pada bulan Nopember yaitu $233 \mathrm{~mm}$ dengan hari hujan sebanyak 12 hari. Sedangkan curah hujan paling kecil terjadi pada bulan Pebruari sebesar $18 \mathrm{~mm}$ dengan hari hujan 2 hari. Rata-rata curah hujan tahun 2008 mencapai 144,67 mm/bulan.

\section{Penduduk dan Tenaga Kerja}

Jumlah penduduk Batu Bara keadaan Bulan Juni Tahun 2008 diperkirakan sebesar 380.570 jiwa dengan kepadatan penduduk sebesar 421 jiwa per $\mathrm{km} 2$. Sebagian besar penduduk bertempat tinggal di daerah pedesaan yaitu sebesar $77.11 \%$ dan sisanya $22.89 \%$ tinggal di daerah perkotaan. Jumlah rumah tangga sebanyak 85.364 rumah tangga dan setiap rumah tangga rata-rata dihuni oleh sekitar 4.5 jiwa, laju pertumbuhan penduduk dari Tahun 2008 sebesar $1.80 \%$.

\section{Pendidikan}

Penyediaan sarana fisik pendidikan dan jumlah tenaga guru yang memadai merupakan salah satu upaya untuk meningkatkan partisipasi sekolah dan kualitas pendidikan masyarakat. Pada Tahun 2008 di Kabupaten Batubara terdapat 16 buah Taman Kanak-kanak dengan jumlah murid 1.410 orang dan guru sebanyak 97 orang.

Sementara itu untuk tingkat Sekolah Dasar terdapat 239 sekolah dengan jumlah murid dan guru masing-masing 
52.381 orang dan 2.383 orang. Untuk tingkat Lanjutan Pertama (SLTP) terdapat 50 sekolah, 14.930 orang murid dan 1.019 orang guru.

Untuk SLTA umum terdapat 19 sekolah dengan jumlah murid 6.681 orang dan guru 436 orang, untuk SLTA kejuruan terdapat 10 sekolah, 234 orang guru dan 3.719 orang murid. Jumlah sekolah menurut jenis dan status sekolah (Batubara Dalam Angka, 2009).

\section{Kesehatan}

Kesehatan merupakan salah satu hal terpenting dalam kehidupan manusia. Dengan tersedianya sarana dan prasarana kesehatan yang memadai sangat membantu dalam upaya meningkatkan kesehatan masyarakat sekaligus meningkatkan kualitas sumber daya manusia. Di Kabupaten Batubara hanya terdapat satu buah Rumah Sakit milik swasta yaitu milik PT. Inalum di Kecamatan Sei Suka. Sedangkan Puskesmas yang ada berjumlah 9 buah juga terdapat Puskesmas Pembantu dan Posyandu masingmasing berjumlah 64 dan 496 buah semuanya tersebar di tiap Kecamatan. Sedangkan jumlah klinik mencapai 145 unit. Fasilitas kesehatan yang ada di Desa Long Uro adalah Puskesmas Pembantu dan baru dibangun tahun 2000. Sumber dana untuk operasional selama ini diberikan oleh Pemerintah Kabupaten.

Keterjangkauan terhadap perawatan kesehatan telah berubah selama 5 tahun terakhir. Jumlah fasilitas kesehatan menurut hasil wawancara bertambah karena dulu kalau mau berobat harus ke Long Ampung atau Long Nawang. Namun jumlah staf masih kurang, juga mengenai alat dan ketersediaan obat masih diharapkan ada penambahan oleh pemerintah. Kalau gaji/honor staf kesehatan dikatakan sama saja belum ada perubahan. Tenaga Medis yang tersedia di
Kabupaten Batubara baik negeri maupun swasta ada 24 orang dokter umum, 8 orang dokter gigi dan tidak ada dokter spesialis.

Sementara itu tenaga medis pemerintah lainnya seperti bidan ada 133 orang, perawat dan pembantu perawat ada 94 orang, juga terdapat 21 orang bidan swasta dan 101 perawat swasta (Data Tahun 2006).

\section{Perikanan}

Produksi ikan laut di Batubara pada Tahun 2008 sebesar 17.800 ton sedangkan produksi ikan darat sebesar 401 ton. Produksi terbesar dihasilkan oleh Kecamatan Tanjung Tiram yaitu sebesar 10.866 ton disusul Kecamatan Medang Deras dengan produksi sebesar 7.111 ton.

Jumlah nelayan di Kabupaten Batubara Tahun 2008 adalah 15.538 orang yang terdiri dari 10.989 orang nelayan penuh, 3.128 orang nelayan sambilan utama dan 1.421 orang nelayan sambilan tambahan. Jumlah rumah tangga budidaya perikanan darat ada sebanyak 709 rumah tangga, terdiri dari 553 rumah tangga petambak dan 156 rumah tangga budidaya kolam. Jumlah alat penangkap ikan menurut jenis yang terdapat di Kecamatan Medang Deras yaitu menggunakan alat jenis sero sebesar 10 , jenis pancing rawai hanyut 8 , jenis pancing rawai tetap 7 , jenis insang hanyut 140 , jenis bubu 20 dan alat pengumpul kerang sebanyak 40 (Batubara Dalam Angka, 2009).

\section{Listrik}

Kebutuhan listrik penduduk Kabupaten Batubara sebagian besar dipasok oleh PLN Ranting Tanjung Tiram. Pada tahun 2008 pada PLN Ranting Tanjung Tiram terdapat 45.288 pelanggan. Sedangkan untuk penjualan listriknya sebesar 24,01 miliar rupiah. Karena sulit untuk memisahkan data, pada cabang 
sementara yang sudah mengajukan permohonan untuk mendirikan perusahaan di kawasan strategis tersebut sudah ada beberapa perusahaan, antara lain: Japan Cilicon Ltd, Kawashima Group, Sungai Lang Marine and Supply Sdn. Bhn. Bhd dan Sungai Pulai Construction and Trading (Batubara dalam Angka, 2009).

Berdasarkan hasil penelitian diketahui bahwa, bantuan pemerintah Kabupaten Batubara masih tergolong minim dalam hal fasilitas kesehatan. Sedangkan pihak swasta/perusahan penanam modal asing (PMA) telah memberikan bantuan dalam bentuk pengobatan gratis sekali dalam 1 tahun dan pelaksanaannya hanya 1 hari di Nanas Siam, Kabupaten Batubara. Pemberian bantuan fasilitas kesehatan oleh pihak swasta merupakan penyaluran dari tanggung jawab sosial perusahaan terhadap lingkungan di sekitar perusahaan yang dikenal dengan istilah Corporate Social Responsibility (CSR) yang harus diberikan oleh setiap perusahaan setiap tahun kepada masyarakat sekitar.

\section{Deskripsi}

Daerah Penelitian Desa Nanas Siam, Kecamatan Medang, Deras Kabupaten Batubara Desa Nanas Saim termasuk di dalam wilayah Kecamatan Medang Deras. Jarak dari Desa Nanas Saim ke Kecamatan Medang Deras sekitar 20 menit dengan alat transportasi angkutan umum. Desa ini terletak di pinggiran Sungai Padang.

Pada umumnya mata pencaharian masyarakat Desa Nanas Siam adalah nelayan sebesar $80 \%$, bertani padi sebesar $15 \%$ dan pegawai sebesar 5\%. Luas Desa Nanas Siam sebesar 697 Ha. Dari 50 orang Kepala Keluarga yang diwawancarai, hampir seluruhnya tergolong usia produktif.

\section{Fasilitas}

Kesehatan Permukiman Kumuh Berdasarkan hasil penelitian diperoleh bahwa, penyakit Malaria, diare dan TBC merupakan penyakit umum yang diderita oleh masyarakat permukiman kumuh di lokasi penelitian, dan perkembangan penyakit ini berfluktuasi dari hari-ke hari. Hal ini disebabkan karena kurangnya kebersihan di sekitar areal permukiman, sehingga penyakit dapat menyebar secara luas di tempat yang kotor. Penyakit malaria dan diare umumnya menyerang anak-anak, sedangkan penyakit TBC umumnya menyerang orang dewasa/lanjut usia.

Perkembangan penyakit tersebut dapat disebabkan karena keterbatasan sulitnya mendapatkan air bersih oleh warga, minimnya fasilitas MCK warga permukiman kumuh di lokasi penelitian. Berdasarkan hasil penelitian kondisi fasilitas posyandu yang ada di Desa Nanas Siam masih sangat minim terbukti karena hanya ada tempat posyandu namun, staf, obat-obatan dan fasilitas lainnya tidak tersedia, posyandu ini aktif hanya pada saat ada bantuan dari pihak pemerintah dan swasta dalam hal pengobatan gratis untuk warga permukiman kumuh.

\section{Listrik}

Penduduk Permukiman Kumuh Penduduk memperoleh listrik kampung sebanyak 37 orang, listrik kelompok sebanyak 5 orang, listrik milik pribadi sebanyak 6 orang dan listrik yang berasal dari PLN sebesar 2 orang. Berdasarkan hasil penelitian listrik PLN semakin sulit dijangkau oleh masyarakat, hal ini dapat disebabkan oleh rendahnya tingkat pendapatan masyarakat permukiman kumuh di Desa Nanas Siam, Kecamatan Medang Deras, Kabupaten Batubara.

\section{Perekonomian}


Masyarakat Permukiman Kumuh Berdasarkan hasil penelitian diperoleh bahwa, sekitar $40 \%$ warga masyarakat tidak mengalami perubahan perekonomian, sekitar $26 \%$ masyarakat menyatakan bahwa perekonomiannya semakin membaik dan 34\% masyarakat mengalami penurunan perekonomian dalam kurun waktu 5 tahun terakhir.

Dari hasil survei diperoleh bahwa pendapatan penduduk rata-rata berkisar antara Rp. 500.000 - Rp. 1.000.000,- per bulan. Namun berdasarkan hasil penelitian kondisi kesehatan masyarakat di Desa Nanas Siam, banyak masyarakat yang masih terserang penyakit malaria, TBC, dan diare.

Berdasarkan hal tersebut diperoleh bahwa penyaluran CSR oleh pihak swasta dinilai kurang efektif untuk daerah permukiman kumuh di lokasi penelitian.

\section{Bantuan Pemerintah Terhadap Pembangunan Desa Nanas Siam}

Berdasarkan hasil kuisioner kepada masyarakat, dalam kurun waktu selama 5 tahun terakhir, pemerintah Kabupaten Medang Deras dinilai tidak ada memberikan bantuan ke masyarakat dalam bentuk apapun. Sedangkan bantuan fasilitas pengobatan gratis selama 2 kali dalam satu tahun diberikan oleh perusahaan swasta seperti PT. Inalum, PT. Domba Mas dan PT. Multi Nabati Asahan.

\section{Kondisi Sosial Ekonomi dan Budaya Masyarakat Permukiman Kumuh}

Berdasarkan hasil penelitian kondisi sosial ekonomi masyarakat yang berada dikawasan pemukiman kumuh antara lain mencakup tingkat pendapatan rendah, norma sosial yang longgar, budaya kemiskinan yang mewarnai kehidupannya yang antara lain tampak dari sikap dan perilaku yang apatis. Kondisi tersebut sering juga mengakibatkan kondisi kesehatan yang buruk, sumber pencemaran, sumber penyebaran penyakit dan perilaku menyimpang, yang berdampak pada kehidupan kota keseluruhannya.

Oleh karena itu kawasan pemukiman kumuh dianggap sebagai penyakit kota yang harus diatasi. Pertumbuhan penduduk merupakan faktor utama yang mendorong pertumbuhan permukiman, sedang kondisi sosial ekonomi masyarakat dan kemampuan pengelola kota akan menentukan kualitas pemukiman yang terwujud. Permukiman kumuh adalah produk pertumbuhan penduduk kemiskinan dan kurangnya pemerintah dalam mengendalikan pertumbuhan dan menyediakan pelayanan kota yang memadai.

Berdasarkan hasil penelitian diperoleh bahwa, terdapat beberapa konflik sosial antar keluarga yang terjadi di masyarakat permukiman kumuh, dan konflik tersebut disebabkan karena pengaruh faktor ekonomi sehingga warga permukiman kumuh sulit untuk mendapat kesejahteraan dalam hal ekonomi keluarga.

\section{Penataan Permukiman Kumuh}

Solusi penataan permukiman kumuh membutuhkan peran semua pihak secara timbal balik, khususnya misi dinas terkait, LSM yang paham kompleksitas permasalahan permukiman kumuh, baik dari segi teknis-teknologis ataupun sosialbudaya, dengan melibatkan partisipasi aktif masyarakat permukiman kumuh itu sendiri.

\section{Faktor-faktor}

kendala pelaksanaan program: kendala dari pihak penentu kebijaksanaan, dipecahkan dengan perbaikan mental dan pemahaman terhadap kebutuhan dari masyarakat 
miskin kota. Kendala dari masyarakat sasaran program dan alternatif yang harus dipecahkan, berupa perbaikan ekonomi, pelayanan kesehatan bagi masyarakat permukiman kumuh di Desa Nanas Siam, kemiskinan, kepribadian dan sikap fatalistik kelompok sosial ini, hal ini sesuai dengan literatur yang dikemukakan oleh Sulistyawati (2007).

\section{KESIMPULAN}

Dari berbagai masalah yang terjadi pada permukiman kumuh di Desa Nanas Siam Kabupaten Batubara, sejak lima tahun terakhir yaitu bahwa hanya dua faktor yang bisa dientaskan yaitu masalah ekonomi dan kesehatan.

Harusnya permukiman kumuh di Desa Nanas Siam harus dilakukan penataan bentuk bangunan penduduk agar terlihat lebih rapi. Perumahan penduduk harus dilengkapi dengan listrik yang memadai di setiap rumah sehingga penduduk permukiman kumuh dapat penerangan/lampu.

$\begin{array}{ccr}\text { Penyaluran } & \text { CSR harusnya } \\ \text { dilakukan melalui } & \text { berbagai bentuk }\end{array}$ tindakan yaitu; menyalurkan air bersih melalui pembuatan sumur bor di lokasi permukiman kumuh sehingga kesehatan penduduk dapat lebih sejahtera dan terhindar dari berbagai penyakit malaria, diare, TBC dan beberapa penyakit kronis lainnya, pemberian beasiswa bagi anak yang putus sekolah agar dapat memperoleh pendidikan sehingga sumber daya masyarakat permukiman kumuh dapat meningkat dengan demikian juga akan meningkatkan kualitas hidup masyarakat permukiman kumuh tersebut di masa depan.

Penyaluran CSR ini tidak dapat terlaksana bila tidak didukung oleh pemerintah Kabupaten Batubara selaku pengambil keputusan dalam pembangunan bersama dengan seluruh perusahaan yang ada di seputaran Desa Nanas Siam untuk membangun rumah penduduk dan menata permukiman dengan tertib dan teratur serta PERBUP (Peraturan Bupati) dalam membangun perumahan di Desa Nanas Saim harus dilaksanakan tegas oleh Pemkab Batubara. Oleh sebab itu maka, untuk mencapai tujuan dalam mensejahterakan masyarakat permukiman kumuh maka permukiman kumuh tersebut harus ditata sebaik-baiknya berdasarkan beberapa faktor dari hasil penelitian ini.

Penulis mengharapkan agar pemerintah Kabupaten Batubara dapat menindaklanjuti hasil penelitian ini sehingga terwujud pembangunan dan penataan permukiman kumuh yang berkelanjutan dan berwawasan lingkungan.

\section{DAFTAR PUSTAKA}

A. dan M. Francis. 1991. Modernisasi di Dunia Ketiga, Suatu Teori Umum Pembangunan. PT. Tiara Wacana Yogya, Yogyakarta.

adan Pusat Statistik Kabupaten Asahan. 2009. Batubara Dalam Angka. BPS Asahan.

B, dan E. 1992. Sejumlah Masalah Permukiman Kota. Alumni, Bandung

B. dan D. 1986. Perumahan dan Permukiman Sebagai Kebutuhan Dasar. Yayasan Obor. Jakarta.

\section{S. 2012. Metode Penelitian Kuantitatif Kualitatif dan R\&D. Bandung: Alfabeta}

S. 2011. Statistika untuk Penelitian. Bandung: Alfabeta

Suliyanto. 2006. Metode Riset Bisnis (EdisiSatu). Yogyakarta: Andi 
T, E. dan K. S. 2005. Pengantar Manajemen. Jakarta: Kencana Prenada Media Group

U, B. 2014. CSR dalam Dunia Bisnis. Yogyakarta: CV. Andi Offset

U, H. dan P.S.A. 2012. Pengantar Statistika. Jakarta: Bumi Aksara 